\title{
Developing PBL Kit by Utilizing Blog in Order to Improve Scientific Process and Problem Solving Skills in Physics Learning
}

\author{
Siti Maria Ulva \\ Universitas Kaltara. Sengkawit Street RT. XVI Tanjung Selor, Regency of Bulungan, North \\ Kalimantan, 77216, Indonesia \\ Email: leleaya3@gmail.com, Telp: (+62552) 23190 \\ Received: 7 April 2017; Revised: 10 May 2017; Accepted: 2 June 2017
}

\begin{abstract}
The study aimed at generating PBL-based learning kit product by utilizing blog, at meeting the criteria of learning kit feasibility, at testing the effectiveness of learning kit that the researcher had developed and at identifying the learning participants' scientific process and problem solving skills. In conducting the study, the researcher implemented the 4-D Model. The learning kit development started involved preliminary study, product design, expert and practitioner test, limited experiment and field experiment. The instruments that had been deployed in conducting the study consisted of validation sheet, learning management observation sheet, student response sheet, teacher interview sheet and learning results test. This study generated a product that consisted of lesson plan, teacher's book, student's book, student's working sheet, blog and learning results assessment. The validation results showed that the learning kit that had been developed were feasible for implementation. Then, the experiment results showed that the learning kit that the researcher had developed met the criteria of effectiveness. Based on the pretest and the posttest results that was administered during the field experiment, students' physics learning has increased approximately 17.10 point from the pretest average score, namely 58.20, and from the posttest average score, namely 75.30.
\end{abstract}

Keywords: PBL, scientific process, problem solving skills

How to Cite: Ulva, S. (2017). Developing PBL kit by utilizing blog in order to improve scientific process and problem solving skills in physics learning. Jurnal Inovasi Pendidikan IPA, 3(1), 89-100. doi:http://dx.doi.org/10.21831/jipi.v3i1.13678

Permalink/DOI: http://dx.doi.org/10.21831/jipi.v3i1.13678

\section{INTRODUCTION}

Physics is one of the subjects that many students are afraid of and tends to be disliked by students as well because in general the children who have mathematical intelligence are the only one who enjoys learning Physics. Physics elaborates and analyzes structures and events that occur in nature, engineering and environment around us. Such dislike appears because within the Physics learning teachers tend to lecture the learning materials informatively without students to discover the Physics material on their own.

Rusman (2011, p. 247) stated that studentcentered is one of the characters that problembased learning has. (Macho-Stadler, 2012, p. 1) stated that problem-based learning (PBL) is a learning method that centers on students by learning through real life and by solving problems in groups. Here, the constructivism theory about learning serves as the philosophical foundation for the model. PBL emphasizes the focus of learning activities on the students' need to invest in their environment and to construct their knowledge personally. Similar to investigation-based, case-study based, jurisprudence investigation-based teaching, PBL demands an environment in which students display mutual respect and tolerance toward ambiguity and differences from one to another (Arends \& Kilcher, 2010, p. 326).

One of the teacher's duties is creating a learning kit before implementing a learning process. Subanindro $(2012$, p. 811$)$ stated that learning kit development will create interactive, inspirational and enjoyable learning activity by using more than one learning methods and such learning kit will challenge and motivate students to take active participation; in the same, such method will also provide sufficient space for 


\section{Jurnal Inovasi Pendidikan IPA, 3 (1), 2017 - 90}

Siti Maria Ulva

innovation, creativity and independence according to the students' talent, interest, physical and psychological development.

Physics is heavily related to problembased learning or PBL. Physics is a subject that mostly studies aspects that have been related to the real life; as a result, studying this subject demands investigation. Learning process conduct by means of PBL implementation in classroom does not only demand reading and listening to the facts and the materials that redefine certain domains of study but also solving realistic problems and making decisions in the daily life (Mergendoller, Maxwell, \& Bellisimo, 2006, p. 49). Furthermore, if the students have lack of information regarding effectiveness then PBL might encouraged the students to learn more on their own (Eldy \& Sulaiman, 2013, p. 347).

Referring to the definition of science, the researcher might conclude that the essence of science includes four main elements namely attitude, process, product and application. Attitude refers to curiosity regarding objects, natural phenomena, living creatures and causality that leads to new problems that might be solved through the appropriate procedures. Process refers to problem solving procedures through scientific method that consists of hypothesis formulation, experiment design, evaluation, measurement and conclusion drawing. Product refers to facts, principles, theories and laws. Finally, application refers to the implementation of scientific methods and scientific materials in the daily life. The four elements are the characteristics of complete science and might not be separated from one to another. Therefore, in order to achieve optimum scientific learning product, students should master scientific process skills in addition to problem solving skills.

There should be innovations in learning activities through several indicators that should be replaced, such as memorization of Physics concepts that should be replaced by mastery of Physics concepts; this mastery, then, might be developed into mastery of scientific generic skills. Departing from this matter, the characteristics of innovative learning process include enjoyable, challenging, active, creative, independent, interactive and inspirational; these characteristics might improve scientific learning results through the process skills. Ongowo \& Indoshi (2013, p. 713) stated that by using 5 out of 12 indicators regarding general process skills both researchers have attained the learning results for each domain as follows: $32.24 \%$ for observation, $14.63 \%$ for communication, $13.13 \%$ for conclusion drawing, $12.21 \%$ for experiment performance and $11.94 \%$ for data interpretation. These results are of higher percentage from the scientific process skills namely $73.73 \%$. Myers \& Dyer (2006, p. 52) stated tat students who have been taught under learning material approach or investigative laboratory approach have higher scientific process skills and material knowledge than those who have been taught under deterministic laboratory approach.

Problem solving is not a separate topic; instead, problem solving is an inherent method in learning process. Malik (2010, p. 17) stated that problem solving involves what should be done in an unkown situation. Shiu, Chien, \& Chung (2011, p. 31) displayed that the posttest results are significantly higher than the pretest results in his study and problem solving test results are significantly higher than normative daya. Problem solving is a process that includes multiple mental skills.

Yasin, Halim, \& Ishar (2012, p. 65) pointed that there have not been significant differences between the control group and the experimental group in terms of students' problem-solving capabilities but the average scores of the experimental group are higher than that of the control group. These results are in accordance to a study by Malik (2010, p. 16), which concluded that students in the experimental group display positive change in their attitude toward the learning process in comparison to those in the control group. This statement confirms that the implementation of problem solving strategy into the learning process successfully improves students' knowledge and achievement.

Based on the interview with Physics teachers from $X$ Grade of SMA Negeri 1 Sedayu, the researcher has information that these Physics teachers have not developed process and capability skills in teaching their students about problem-solving activities. One of the important learning materials in Physics is optical device. The materials of optical device are a concrete example and these materials have many applications in the daily life; however, in the reality students still have difficulties in understanding these materials. Students only memorize the materials and are less able to apply these materials when they encounter the 


\section{Jurnal Inovasi Pendidikan IPA, 3 (1), 2017 - 91}

Siti Maria Ulva

materials-related problems in the real life. Furthermore, students are also less able to define and to formulate their problems.

Physics learning process both in classroom and in laboratory is still teachercentered; as a result, teachers still dominate the learning process. Teachers have not possessed awareness to provide more independence for their students in developing their own capabilities (student-centered). Teachers only feel that they are successful when their students have been able to complete the calculation-test items that they assign. The teachers have not possessed awareness to develop the students' process and problem solving skills as well and they still tend to use conventional learning method.

Based on the results of observation that had been conducted, SMA Negeri 1 Sedayu has already had very supporting facilities but these facilities are less utilized in the learning process. One of the facilities that have been less utilized is related to Information and Communication Technology namely Wi-Fi. This facility has been widespread throughout the senior high school but it is less utilized by teachers; instead, it is more utilized by students only for accessing social networks that have been widespread among the students and the nearby society. The utilization of this facility is certainly supported by the gadgets that students have. This facility actually might be utilized by teachers to perform online learning in order to develop students' capabilities. However, in the practice the teachers do not utilize the facility for performing learning process. It is suggested that teachers should utilize the Wi-Fi network in the school and the gadgets that students for the sake of the learning process.

Online learning that has been well-known nowadays is an Internet application that might serve as connecting media/device between teachers and students in an online learning room. Abundant information that has been available on the Internet will ease students to search ore information, to share their opinions or to have discussions through multiple media such as e-mail, blog, online forum and alike (Fariz, Ajie, \& Duskarnaen, 2014, p. 1). The utilization of Wi-Fi network in the school is expected to ease students to find information regarding the materials that have been taught so that teachers might develop the students' capabilities. Teachers might utilize online software that have been easily available so that they might write in sufficient space by utilizing only one type of sites namely blog.

Looking at the problems that have been elaborated, there should be development of PBL-based learning kit by means of blog utilization in order that teachers might provide more independence to students in developing their own capabilities. Learning by means of PBL model is one approach that teachers might select. PBL starts from the presence of problems (displayed by teachers or students). Then, students deepen their knowledge regarding what they have learned and what they should know in order to solve the problem. Students might select problems that the consider interesting to be solved so that they will be encouraged to take active participation in order to improve their process problem-solving skills.

\section{METHOD}

The study was a research and development. The model of this study was adapted from 4-D type that had been developed by Thiagarajan and the 4-D type consisted of define, design, develop and disseminate.

However, the researcher only performed three out of four stages from the 4-D type namely define, design and disseminate. Define stage aimed at implementing and at defining learning requirements. In this stage, there were activity steps for development. This stage consisted: (1) pre-study, which aimed at displaying fundamental problem that would be necessary for developing learning materials; (2) study analysis, which aimed at reviewing students' background regarding their knowledge and cognitive development and this will be students' initial equipment in relation to product, process and psychomotor learning; (3) task analysis, which aimed at attaining details of learning materials in the form of guidelines and this task analysis consisted of content structure analysis and procedural analysis; (4) concept analysis, which aimed at identifying, detailing and arranging the map of material concepts that students would learn; and (5) learning objective formulation, which aimed at attaining the achievement of Competency Standards/Basic Competencies based on the material analysis that had been designed previously. Then, Develop stage aimed at generating a draft of learning kit that had been revised based on the suggestions by the experts. This stage consisted expert appraisal for attaining the experts' validity regarding the learning kit that had been 


\section{Jurnal Inovasi Pendidikan IPA, 3 (1), 2017 - 92}

Siti Maria Ulva

design and developmental test which involved limited experiment and field experiment.

\section{Product Design Experiment}

The experiment in this study consisted $\mathrm{f}$ three stages namely expert judgment, limited experiment and field experiment. Expert judgment aimed at attaining assessment from the experts regarding the PBL learning kit that utilized blog and at testing the learning results especially students' scientific process and problem solving skills. The test would deal with whether the skills that the students develop had been valid or not. Limited experiment was conducted in order to see the effectiveness of PBL learning kit that utilized blog and the results of assessment test that had been developed.

The subjects in this study were divided into three tests as follows: experts and practitioners tests, which subjects were materialexpert lecturer, media expert, teachers and peers; limited experiment, which subjects were students from the X Grade of Natural Science Program SMAN 1 Sedayu; and field experiment, which subjects were 64 students from SMAN 1 Sedayu who consisted of two classrooms namely X Natural Science 2 (the control group) and $\mathrm{X}$ Natural Science 4 (the experimental group). The data that had been attained in this study were qualitative and quantitative. The qualitative data were the comments provided by validators, while the quantitative data were the assessment scores.

The techniques that the researcher implemented in gathering the data were documentation, questionnaire, test and observation. Then, the data gathering instruments consisted of validation sheet, practicality assessment sheet for teachers and students, observation sheet for syntax implementation and students' problemsolving capabilities test.

The results of data analysis that had been attained by the experts and the practitioners were used in determining the validity of the product that had been resulted in terms of theory and in terms of consistency among the components of the product that had been developed. The results of data analysis from the field experiment were used as the basis for determining the practicality and the effectiveness of the product that had been developed. For this purpose, the researcher should design a conversion table. The conversion table was designed by converting the scores of expert judgment, teacher/practitioner judgment and student judgment into the standard five-scale scores. In this study, the conversion referred to the data conversion that had been adapted from Azwar (2010, p. 163). The conversion was displayed in Table 1 as follows.

Table 1. Conversion from Quantitative Data to Qualitative Data

\begin{tabular}{cc}
\hline Interval & Criteria \\
\hline$M i+1,5 S B i<\mathrm{M}$ & Very Good \\
$M i+0,5 S B \mathrm{i}<\mathrm{M} \leq M i+1,5 \mathrm{SBi}$ & Good \\
$M i-0,5 \mathrm{SB} i<\mathrm{M} \leq M i+0,5 \mathrm{SBi}$ & Moderately Good \\
$\mathrm{Mi}-1,5 \mathrm{SBi}<\mathrm{M} \leq \mathrm{Mi}-0,5 \mathrm{SBi}$ & Poor \\
$\mathrm{M} \leq \mathrm{Mi}-1,5 \mathrm{SBi}$ & Worse \\
\hline
\end{tabular}

Note:

$\mathrm{M}$ was the actual score, Mi was $1 / 2$ of maximum ideal score + minimum ideal score and SBi was $1 / 6$ of maximum ideal score-minimum ideal score.

The analysis technique for the validity data included each component in the product that had been developed namely: lesson plan, teacher's book, student's book, student's development report, blog and problem solving capabilities test. The data analysis was conducted by converting the quantitative data in the form of assessment scores for each component into the qualitative data. During the period of main field experiment, the data were analyzed by means of multivariate/Hotelling's $\mathrm{T}^{2}$ and gain score (Hake, 1998, p. 8). In conducting this differential test, the researchers administered requirement test, namely normality test by means of Kolmogorov-Smirnov statistical test, and homogeneity test, namely Levene statistical test by means of SPSS 20 for Windows.

\section{RESULTS AND DISCUSSIONS}

The results of this study were PBL-based Physics learning kit that utilized blog under the theme "Optical Device." The components of this learning kit would be explained in the following paragraphs.

The first component was lesson plan. Lesson plan contained the identity (school name, subject, grade/semester, main material and time allocation); competence formulation (core competencies, basic competencies, basic competency achievement and learning objectives); learning materials; learning model, approach and method; learning media, tools and sources; learning activities; and assessment (assessment technique, instrument and instrument example). The lesson plan was designed by implementing PBL syntax under the theme "Optical Device." 


\section{Jurnal Inovasi Pendidikan IPA, 3 (1), 2017 - 93}

Siti Maria Ulva

The lesson plan covered three meetings. The first meeting discussed the learning materials of eyes, glasses and magnifying glass. The second meeting discussed the learning materials of camera and microscope. The third meeting discussed the learning materials of binoculars.

The second component was teacher's book. The teacher's book that had been developed contained title, forewords, table of content, general guidelines of Physics learning process in senior high school, learning materials of optical device, glossary, list of references and index. The content of general guidelines of Physics learning process in senior high schools contained introduction, learning strategy, PBL (problem-based learning) based learning process/activities, Physics learning media and assessment in Physics learning process. Then, the content of the learning materials of optical device in the teacher's book that had been developed included introduction, core competencies and basic competencies, main learning materials of optical device, summary, assessment, form of communication with parents/ foster parents, enrichment and answer keys.

The third component was student's book. The student's book that had been developed included the following contents: title, forewords, table of content, optical device, concept map, competence test, glossary, list of references, answer keys and index. The contents of optical device were eyes and glasses, magnifying glass, camera, microscopes, binoculars and summary.

The fourth component was student's working sheet (LKPD, Lembar Kerja Peserta Didik). The student's working sheet contained title, material summary, problem orientation, learning objectives, tools and materials, problem formulations, hypothesis, observation procedures, data from observation results, data analysis, conclusion and applied problems that had been adjusted to the activities that had been performed. The student's working sheet contained experimental activities that students would perform. The student's working sheet that had been developed consisted of four sheets. The first sheet contained the experimental activities in relation to eyes and glasses. The second sheet contained the experimental activities in relation to magnifying glass. The third sheet contained the experimental activities in relation to microscopes. The fourth sheet contained the experimental activities in relation to binoculars.
The fifth component was blog. The blog that had been developed in this study contain the PBL-based learning materials of optical device and the menu of optical device assignment that contained the test items and the guidelines in completing those test items. The blog might be accessed through http://www.fisikaoptiksma.blogspot.com. The blog that had been developed in the study did not only contain the materials that students might access but also the provision of optical device test items that might be completed online. The test items that might be completed online utilized the Edmodo application.

The sixth component was authentic assessment instrument. The authentic assessment instrument that had been developed contained knowledge and skills assessment. The knowledge assessment was in the form of narrative test items, while the skills assessment was in the form of observation sheet. Each instrument was equipped by guidelines, scoring rubric and assessment guidelines.

Table 2. Summary on the Results of Learning Kit Feasibility Test

\begin{tabular}{|c|c|c|}
\hline No. & Aspects & Note \\
\hline 1. & $\begin{array}{l}\text { Lesson plan assessment and } \\
\text { validation by the expert lecturers, } \\
\text { the teachers and the colleagues }\end{array}$ & $\begin{array}{c}\text { Very } \\
\text { Good + } \\
\text { Minor } \\
\text { Revision }\end{array}$ \\
\hline 2. & $\begin{array}{l}\text { Teacher's book assessment and } \\
\text { validation by the expert lecturers, } \\
\text { the teachers and the colleagues }\end{array}$ & $\begin{array}{c}\text { Very } \\
\text { Good }+ \\
\text { Minor } \\
\text { Revision }\end{array}$ \\
\hline 3. & $\begin{array}{l}\text { Student's book assessment and } \\
\text { validation by the expert lecturers, } \\
\text { the teachers and the colleagues }\end{array}$ & $\begin{array}{l}\text { Very } \\
\text { Good + } \\
\text { Minor } \\
\text { Revision }\end{array}$ \\
\hline 4. & $\begin{array}{l}\text { Student's working sheet assessment } \\
\text { and validation by the expert } \\
\text { lecturers, the teachers and the } \\
\text { colleagues }\end{array}$ & $\begin{array}{c}\text { Very } \\
\text { Good }+ \\
\text { Minor } \\
\text { Revision }\end{array}$ \\
\hline 5. & $\begin{array}{l}\text { Blog assessment and validation by } \\
\text { the expert lecturers, the teachers and } \\
\text { the colleagues }\end{array}$ & $\begin{array}{c}\text { Very } \\
\text { Good + } \\
\text { Minor } \\
\text { Revision }\end{array}$ \\
\hline 6. & $\begin{array}{l}\text { Scientific process and problem- } \\
\text { solving skills observation } \\
\text { instrument assessment and } \\
\text { validation by the expert lecturers, } \\
\text { the teachers and the colleagues }\end{array}$ & $\begin{array}{c}\text { Very } \\
\text { Good }+ \\
\text { Minor } \\
\text { Revision }\end{array}$ \\
\hline 7. & $\begin{array}{l}\text { Problem-solving skills test } \\
\text { instrument assessment and } \\
\text { validation by the expert lecturers, } \\
\text { the teachers and the colleagues }\end{array}$ & $\begin{array}{c}\text { Very } \\
\text { Good }+ \\
\text { Minor } \\
\text { Revision }\end{array}$ \\
\hline
\end{tabular}

The learning kit feasibility was measured through the validators' judgment and the learning kit product effectiveness test. Then, the 


\section{Jurnal Inovasi Pendidikan IPA, 3 (1), 2017 - 94}

Siti Maria Ulva

limited experiment and the field experiment were conducted in order to improve the scientific process and problem-solving skills. The summary on the results of the feasibility test toward the learning kit that the researcher had developed might be viewed in Table 2 .

The results of validation from each learning kit component that consisted of lesson plan, teacher's book, student's book, student's working sheet, blog observation sheet of scientific skill process and problem-solving test resulted in "A" score with "very good" category from expert lecturers, Physics teachers and colleagues. The validators' judgment in each component of learning kit had exceeded the minimum score that the researcher determined namely B ("good" category). This score implied that the learning kit components that had been developed both individually and communally had been feasible for experiment according to the validators' judgment. In addition to judging the learning kit, the validators also provided their suggestions regarding the learning kit revision. All of the constructive suggestions that the validators provided had given attention in order to revise the learning kit.

The descriptive results of students' response in this study were classified into two groups namely: (1) students' responses toward the Physics learning kit that consisted of student's book, student's working sheet and blog; and (2) students' responses toward the learning process that utilized the PBL-based learning kit.

Students' response toward the student's book showed that the content of the book had been easy to understand and the materials that were presented had been interesting and had been able to expand their knowledge. In general, the students might understand the student's book easily although there were several questions regarding the terms that they had not understand in the book. Thereby, the researcher might state that the language (including the sentences) that had been applied in the student's book had been in accordance to the proficiency level of senior high school students. The assessment toward the student's book was attained in the field experiment. The aspects of the student's book that had been assessed were the aspects of layout and of language/readability. The results of student's book assessment resulted in "Very Good" category based on the assessment that had been provided by the material experts, Physics teachers and five colleagues; as a result, the student's book that had been developed was considered feasible for implementation.

The students' response toward the student's working sheet showed that after the administration of limited experiment the student's working sheet had minor changes. Based on the suggestions that had been provided by the students in the limited experiment (the first experiment), the researcher found that the observation procedures had been lack of pictures; as a result, the students had difficulties in understanding the laboratory practice procedures. Basically, the student's working design were design in order to assist the learning process in certain chapters. The student's working sheet contained directions that emphasized whether the students should work independently or cooperatively. The questions in the student's working sheet should be in accordance to the learning objectives. These questions might be applied in the simple or the complex problems. In order to measure the degree of capabilities (especially in the cognitive aspects), the questions or the problems were usually packaged from the lower level to the higher level. After the student's working sheet had been revised, the resulted student's working sheet was ready for the expanded experiment or the field experiment. The results of the expanded or the field experiment showed that the student's response toward the student's working sheet contained direction clarity, attraction and materials that had been presented might increase the knowledge with "very good" category.

The students' responses toward the blog showed that the data from the limited experiment caused the blog to undergo several changes. Based on the suggestions that the students provided in the limited experiment (the first experiment), the blog's layout had been interesting and for this aspect there had not been any changes. On the contrary, based on the results of the expert judgment or validation, the blog's layout had been good but the very aspect that should be revised was the blog's content. The experts suggested adding one of the available free features in order to complete the blog's content. This completion should be conducted in order that the content would not only serve as the material or the document storage but also display the features that might improve the students' process and problemsolving skills. Therefore, the blog was revised by adding a technical assignment feature namely 


\section{Jurnal Inovasi Pendidikan IPA, 3 (1), 2017 - 95}

Siti Maria Ulva

Edmodo. The Edmodo feature would be useful for the students so that they could complete their assignment online and they could train their discipline in completing the test items on time because the time in this feature might be set. As a result, the teachers might check whether their students had completed the test items on time or not. After the blog had been revised, the researchers produced a new blog that would be ready for the expanded or the field experiment.

In the expanded experiment, the students who belonged to the experimental group were asked to complete the online test items after the learning process had been done in the classroom. These test items were useful for improving their scientific process skills in solving problems. The test items that had been completed were located in the blog that had been developed. Because of the Edmodo feature addition, the students were able to complete the test items online. First of all, the students accessed the blog in which they would find the materials that they could use as the sources in completing the test items. Before the students completed the test items, they were asked to open the guidelines first so that they would not be confused after they had done completing the test items that had been given.

According to the observation results, the students were very enthusiastic in completing the online test items. During the expanded experiment, there had not been any obstacles in the online test item completion because the senior high school students had been supported by their gadgets and the Internet access. Based on the results of 5-scale score conversion, in general the students' response toward the blog in terms of "Template" aspect had been "Good." Then, in general the students' response toward the blog in terms of "Home (Front Page" aspect had also been good."

The students' responses toward the learning process were gathered through the students' response questionnaire, namely their opinion toward the learning process. This questionnaire was distributed to the students at the end of PBL-based learning kit by means of blog utilization experimental activities. The experiment of this learning kit took place approximately for three weeks. The students were asked to complete the questionnaire honestly. Based on the results of 5-scale score conversion, the students' responses toward the learning process in terms of lesson plan implementation, scientific process skills development and problem-solving skills development in general had been "Good."

Table 3. Summary on the Results of Experiment Results

\begin{tabular}{|c|c|c|}
\hline No. & Aspects & Note \\
\hline 1. & $\begin{array}{l}\text { Assessment of lesson plan } \\
\text { implementation results by } \\
\text { the teachers }\end{array}$ & Very Good \\
\hline 2. & $\begin{array}{l}\text { Assessment of students' } \\
\text { responses toward the } \\
\text { learning process }\end{array}$ & Good \\
\hline 3. & $\begin{array}{l}\text { Assessment of students' } \\
\text { responses toward the } \\
\text { student's book }\end{array}$ & Very Good \\
\hline 4. & $\begin{array}{l}\text { Assessment of students' } \\
\text { responses toward the } \\
\text { student's working sheet }\end{array}$ & Very Good \\
\hline 5. & $\begin{array}{l}\text { Assessment of students' } \\
\text { responses toward the blog }\end{array}$ & Good \\
\hline 6. & $\begin{array}{l}\text { Assessment of scientific } \\
\text { process results for: } \\
\text { Experimental group } \rightarrow \\
\text { Control group } \rightarrow\end{array}$ & $\begin{array}{l}\text { Good } \\
\text { Poor }\end{array}$ \\
\hline 7. & $\begin{array}{l}\text { Assessment of problem- } \\
\text { solving skills for: } \\
\text { Experimental group } \rightarrow \\
\text { Control group } \rightarrow\end{array}$ & $\begin{array}{l}\text { Gain standard } \\
\text { had been equal } \\
\text { to } 0.42 \\
\text { Gain standard } \\
\text { had been equal } \\
\text { to } 0,37\end{array}$ \\
\hline
\end{tabular}

The results of the field experiment showed that the lesson plan had been implemented in accordance to the scenario although the implementation had not been $100.00 \%$. Based on the results of 5-scale score conversion, the assessment toward the lesson plan implementation in the first, the second and the third meeting fell into the "Very Good" category. The $\mathrm{R}$ value for each meeting, respectively, was $87.40 \%, 82.20 \%$ and $89.30 \%$. The learning activities in the experimental group and the control group were conducted for three meetings. In the first meeting, the learning activities were identifying, analyzing and observing eyes and magnifying class. In the second meeting, the learning activities were identifying, analyzing and observing camera and microscope. In the third meeting, the learning activities were identifying, analyzing and observing binoculars. The activities of PBLbased learning kit by means of blog utilization that had been conducted was in accordance to the lesson plan, the teacher's book, the student's book, the student's working sheet and the blog that had been developed. In every meeting, the learning activities were observed by two persons 
in order to assess the lesson plan implementation. The aspect under observation was the implementation of PBL syntax which covered introductory activities, core activities and closing activities. The bar diagram for the results of observation on the lesson plan implementation was shown in Figure 1.

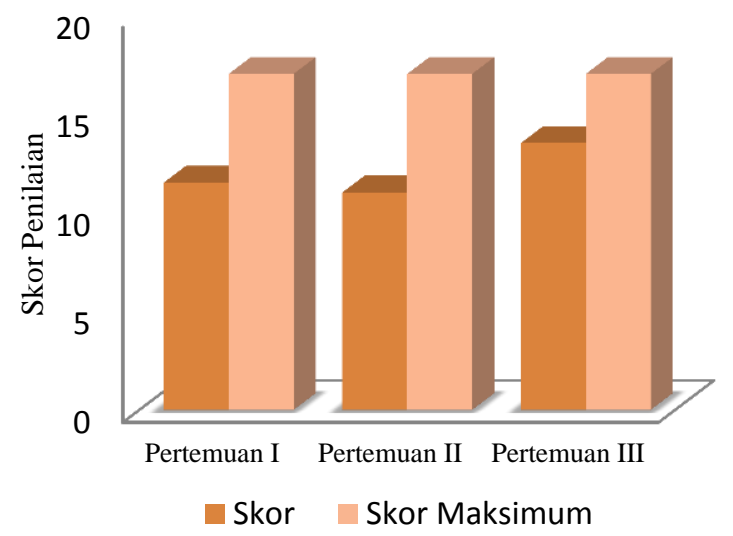

Figure 1. The Graphic of Lesson Plan Implementation Results in the Field Experiment

The data on the students' process skills were gathered from the results of observation during the learning process. The observation was conducted in order to identify the skills that appeared during the learning process. The results of the observation on the scientific process skills might be viewed in Figure 2. The learning process in the experimental group made use of the learning kit that the researcher had developed, while the learning process in the control group made use of the learning kit that the teacher develop. The aspect of scientific process skills that had been developed in this study was the integrated scientific process skills, which covered the variable identifying skills, the formulating hypotheses skills, the designing experiment skills, the performing experiment skills, the designing data table skills, the analyzing data skills and the drawing conclusions skills.

Based on the results of 4-scale score conversion, the identifying variable skills in the experimental group fell into the "Good" category (2.90) while those in the control group fell into the "Moderately Good" category (1.90). The formulating hypotheses skills in the experimental group fell into the "Good" category (3.10) while those in the control group fell into the "Moderately Group" category (2.40). The designing experiment skills in the experimental group fell into the "Good" category (3.20) while those in the control group fell into the "Moderately Good" category (2.10). The performing experiment skills in the experimental group fell into the "Good" category (3.30) while those in the control group fell into the "Moderately Group" category (2.20). The designing data table skills in the experimental group fell into the "Very Good" category (3.30) while those in the control group fell into the "Good" category (2.50). The analyzing data skills in the experimental group fell into the "Good" category (3.00) while those in the control group fell into the "Poor" category (1.60). The drawing conclusion skills in the experimental group fell into the "Good" category (3.10) while those in the control group fell into the "Moderately Good" category (2.40).

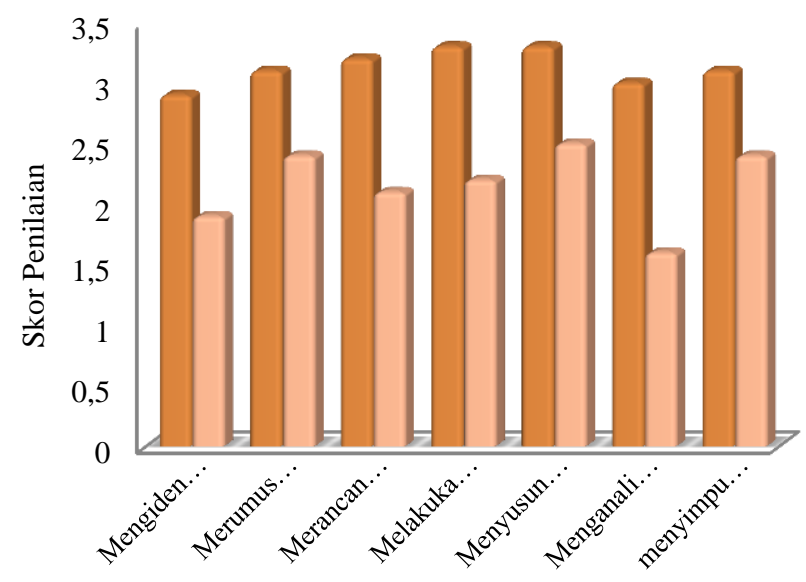

Figure 2. The Graphic of Scientific Process Skills Achievement in the Experimental Group and the Control Group

The aspects of process skills that had been developed also appeared in the learning process. The learning process in the experimental group was designed to develop the process skills through the PBL-based learning process. During the learning process, the students in the experimental group were guided to perform investigation. The teacher provided problems that had been related to the learning materials of optical device; then the students performed an investigation like a scientist did. The students performed the investigation according to the activities in the student's working sheet that had been developed. The activities in the student's working sheet was designed to develop the identifying variable skills, the formulating 
hypotheses skills, the designing experiment skills, the performing experiment skills, the designing data table skills, the analyzing data skills and the drawing conclusions skills.

The data of mean gain standard from the results of observation toward the scientific process skills in the experimental group and the control showed that the mean gain standard that the experimental group had resulted was equal to 0.41 while the mean gain standard that the control group had resulted was equal to 0.25 . This difference implied that the improvement of scientific process skills for the experimental group had been greater than that for the control group. The gain standard graphic for the scientific process skills between the experimental group and the control group might be viewed in Figure 3.

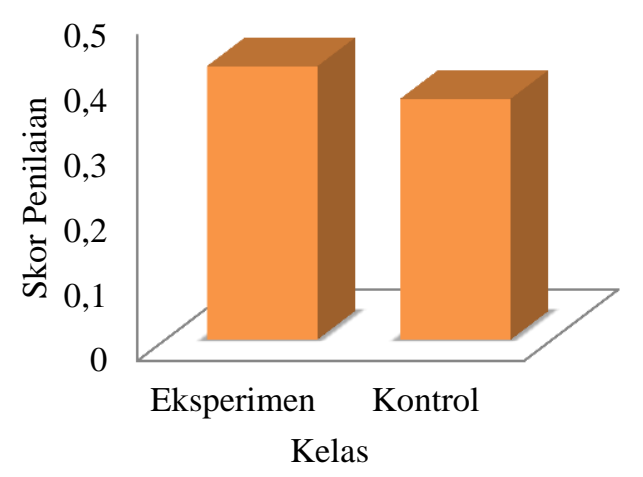

Figure 3. The Graphic of Gain Standard for the Scientific Process Skills between the Experimental Group and the Control Group

The learning process in the experimental group made use of the learning kit that the researcher had developed, while that in the control group made use of the learning kit that the researcher had developed by the teacher. Both groups displayed improvement on their scores and their pretest-posttest scores; however, the improvement of the experimental group was higher than that of the control group. The mean of pretest, posttest and gain score for problemsolving skills of both the experimental and the control group displayed improvement. The improvement that the experimental and the control group attained, respectively, was 0.42 and 0.37. These findings showed that the experimental group's improvement had been higher than the control group's improvement. The mean of gain standard for the problem- solving skills of both the experimental and the control group might be viewed in Figure 4.

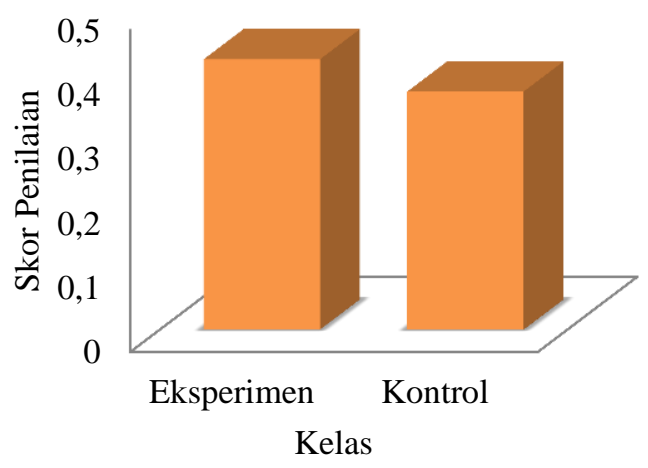

Figure 4. Gain Standard for Problem-Solving Skills of Both the Experimental and the Control Group

The data analysis toward the students; scientific process and problem-solving skills was conducted in order to identify the differences on the improvement of scientific process and problem-solving skills between the experimental group and the control group. A requirement test that should be completed before the multivariate test would be conducted was the normality test and the homogeneity test.

The normality test was conducted in order to identify whether the data distribution had been normal or not. The normality test was conducted toward the data of gain standard for the scientific process and problem-solving skills between the experimental group and the control group. A summary on the results of normality test by Kolmogorov-Smirnov test might be viewed in Table 4. Based on the results of normality test that had been displayed in Table 4 , the researcher found that the significance value of gain standard for the scientific process and problem-solving skills between the experimental group and the control group > 0.05 ; therefore, $\mathrm{H}_{0}$ was accepted. These findings implied that the data of gain standard for the scientific process and problem-solving skills had been normally distributed.

The variance homogeneity test was conducted toward the data of gain standard for the scientific process and problem-solving skills. The homogeneity test was conducted by Levene test with significance rate at 5\%. A summary on the results of homogeneity test by Levene might be viewed in Table 5. Based on the results of homogeneity test that had been displayed in 
Table 5, the researchers found that the significance value of gain standard for the scientific process and problem-solving skills > 0.05 ; as a result, $\mathrm{H}_{0}$ was accepted. These findings implied that the gain standard for the scientific process and problem-solving skills had relatively similar variance.

Table 4. The Results of Normality Test by Kolmogorov-Smirnov Test

\begin{tabular}{|c|c|c|c|c|}
\hline \multirow[t]{2}{*}{ Group } & \multirow{2}{*}{$\begin{array}{l}\text { Dependent } \\
\text { Variables }\end{array}$} & \multicolumn{3}{|c|}{$\begin{array}{l}\text { Kolmogorov- } \\
\text { Smirnov }\end{array}$} \\
\hline & & Statistic & df & Sig. \\
\hline \multirow{2}{*}{ Experimental } & $\begin{array}{l}\text { Gain } \\
\text { standard for } \\
\text { the scientific } \\
\text { process skills }\end{array}$ & 0.156 & 31 & 0.052 \\
\hline & $\begin{array}{l}\text { Gain } \\
\text { standard for } \\
\text { the problem- } \\
\text { solving skills }\end{array}$ & 0.142 & 31 & 0.111 \\
\hline \multirow{2}{*}{ Control } & $\begin{array}{l}\text { Gain } \\
\text { standard for } \\
\text { the scientific } \\
\text { process skills }\end{array}$ & 0.124 & 31 & 0.200 \\
\hline & $\begin{array}{l}\text { Gain } \\
\text { standard for } \\
\text { the problem- } \\
\text { solving skills }\end{array}$ & 0.090 & 31 & 0.200 \\
\hline
\end{tabular}

Table 5. The Results of Homogeneity Test for the Gain Standard of Scientific Process and Problem-Solving Skills

\begin{tabular}{cccccc}
\hline No. & $\begin{array}{c}\text { Dependent } \\
\text { Variables }\end{array}$ & $\begin{array}{c}\text { Levene } \\
\text { Statistic }\end{array}$ & $\mathbf{d f}_{\mathbf{1}}$ & $\mathbf{d f}_{\mathbf{2}}$ & Sig. \\
\hline 1. $\begin{array}{l}\text { Gain standard } \\
\text { for the scientific } \\
\text { process skills }\end{array}$ & 2.171 & 1 & 59 & 0.146 \\
$\begin{array}{l}\text { Gain standard } \\
\text { for the problem- } \\
\text { solving skills }\end{array}$ & 1.459 & 1 & 59 & 0.122 \\
\hline
\end{tabular}

After all of the requirement tests had been completed, the researchers might proceed to the multivariate test. The dependent variables in this study were the scientific process and problemsolving skills. The multivariate test was conducted in order to identify the differences on the average improvement of scientific process and problem-solving skills between the experimental group and the control group. The gain standard differential test for the scientific process and problem-solving skills was conducted by Multivariate Test/Hotelling's $\mathrm{T}^{2}$ with significance rate at $5 \%$. A summary on the results of Multivariate Test/Hotelling's $\mathrm{T}^{2}$ might be viewed in Table 6 .
The results of Hotelling's $\mathrm{T}^{2}$ test for the gain standard of scientific process and problemsolving skills that had been displayed in Table 6 implied that the significance value < 0.05 ; as a result, $\mathrm{H}_{0}$ was rejected. Based on the results of hypothesis test by Hotelling's $\mathrm{T}^{2}$, the researcher might conclude that there had been significant differences on the improvement of scientific process and problem-solving skills between the experimental group that had been provided with the PBL-based Physics learning kit by means of blog utilization and the control that had been provided with the learning kit that the teacher had developed.

Table 6. Results of Hotelling's $\mathrm{T}^{2}$ Test for the

Gain Standard of Scientific Process and Problem-Solving Skills

\begin{tabular}{|c|c|c|c|c|c|}
\hline Effect & Value & $\mathbf{F}$ & $\begin{array}{l}\text { HypothesisE } \\
\text { df }\end{array}$ & $\begin{array}{l}\text { Error } \\
\text { df }\end{array}$ & Sig. \\
\hline $\begin{array}{l}\text { Hotelling's } \\
T^{2}\end{array}$ & 0.456 & 13.454 & 2 & 59 & 0.001 \\
\hline
\end{tabular}

\section{CONCLUSIONS AND SUGGESTIONS}

This study generates a product in the form of PBL-based Physics learning kit. The components of the learning kit that the researcher has developed are lesson plan, teacher's book, student's books, student's working sheet, blog and learning results assessment especially for the scientific process and problem-solving skills. The learning kit that the researcher has developed meets the criteria of feasibility. The statement is based on the results of validation that has been conducted by the material expert lectures, the media experts, the Physics teachers and the colleagues. The results that have been attained in each component of the learning kit that the researcher has developed has "Very Good" category; as a result, this learning kit is feasible for implementation in the Physics learning process.

The results of observation toward the implementation of learning syntax that has been performed falls into the "Effective" category, because in the observation the implementation of learning syntax in the three meetings falls into the "Very Good" category. The percentage that has been attained in each meeting, respectively, is $87.40 \%, 82.20 \%$ and $89.30 \%$. The learning process in the experimental group makes use of the learning kit that the researcher has developed, while that in the control group makes of the learning kit that the teacher has developed. Both groups have improvement on 
their scores and their pretest-posttest results; however, the improvement of the experimental group is higher than that of the control group. The mean of gain standard for the experimental group is equal to 0.42 , while that for the control group is 0.37 . These findings imply that the improvement of the problem solving skills for the experimental group has been higher than that for the control group.

The PBL-based learning kit by means of blog utilization is a product that has been expected to be implemented into Physics learning process in schools. The Physics learning is expected to emphasize more on the process and the problem-solving skills through the implemented of PBL-based Physics learning kit by means of blog utilization. The PBL-based Physics learning kit by means of blog utilization is a learning process that might students into active participation during the learning process and that might develop their scientific process and problem-solving skills.

For the further development of the product that has been generated in the study, the researcher would like to suggest that the PBLbased learning kit by means of blog utilization might be followed up by the further researchers through the dissemination in several different schools. The PBL-based Physics learning kit might be developed further for learning materials that have factual, conceptual and procedural characteristics.

\section{REFERENCES}

Arends, R. I., \& Kilcher, A. R. (2010). Teaching for student learning: Becoming an accomplished teacher. Routledge. New York: Taylor \& Francis e-Library. http://doi.org/10.4324/9780203866771

Azwar, S. (2010). Tes prestasi: Fungsi dan pengembangan pengukuran prestasi belajar. Yogyakarta: Pustaka Belajar. http://doi.org/1998

Eldy, E. F., \& Sulaiman, F. (2013). The capability of integrated problem-based learning in improving students ${ }^{\text {ee }}$ level of creative-critical thinking. International Journal of E-Education, E-Business, EManagement and E-Learning, 3(4), 347350.

http://doi.org/10.7763/IJEEEE.2013.V3.25 7

Fariz, A., Ajie, H., \& Duskarnaen, M. F. (2014). Pengembangan media pembelajaran berbasis web pada mata pelajaran perakitan komputer di SMK 3 perguruan Cikini. Jakarta: Universitas Negeri Jakarta.

Hake, R. R. (1998). Interactive-engagement versus traditional methods: A sixthousand-student survey of mechanics test data for introductory physics courses. American Journal of Physics, 66(1), 6474. http://doi.org/10.1119/1.18809

Macho-Stadler, E. (2012). Analysis of an experience of problem based learning in a physics course of technical telecommunications engineering degree. New Perspectives in Science Education. Retrieved from http://conference.pixelonline.net/science/common/download/Pap er_pdf/46-STM08-FP-MachoStadlerNPSE2012.pdf

Malik, M. A. (2010). Effect of problem solving teaching strategy on 8th grade student's attitude towards science. Journal of Education and Practice, 1(3), 16-27. Retrieved from http://www.iiste.org/Journals/index.php/JE $\mathrm{P} /$ article/view/1658

Mergendoller, J. R., Maxwell, N. L., \& Bellisimo, Y. (2006). The effectiveness of problem-based instruction: a comparative study of instructional methods and student characteristics. Interdisciplinary Journal of Problem-Based Learning, 1(2). http://doi.org/10.7771/1541-5015.1026

Myers, B. E., \& Dyer, J. E. (2006). Effects of investigative laboratory instruction on content knowledge and science process skill achievement across learning styles. Journal of Agricultural Education, 47(4), $52-63$.

http://doi.org/10.5032/jae.2006.04052

Ongowo, R. O., \& Indoshi, F. C. (2013). Science process skills in the Kenya certificate of secondary education biology practical examinations. Creative Education, 4(11), 713-717. http://doi.org/10.4236/ce.2013.411101

Rusman. (2011). Model-model pembelajaran: Mengembangkan profesionalisme guru. Jakarta: Rajawali Pers.

Shiu, S.-C., Chien, H.-O., \& Chung, R.-G. (2011). A study of learning process to promote the ability of creativity and creative problem solving in the Technological University Student. 
International Journal of Arts \& Sciences, $4(8), 31-36$.

Subanindro, S. (2012). Pengembangan perangkat pembelajaran trigonometri berorientasikan kemampuan penalaran dan komunikasi matematik siswa SMA. In Seminar Nasional Matematika dan Pendidikan Matematika 2012. Yogyakarta: Jurusan Pendidikan Matematika, Fakultas
Matematika dan Ilmu Pengetahuan Alam, Universitas Negeri Yogyakarta. Retrieved from http://eprints.uny.ac.id/10099/

Yasin, R. M., Halim, L., \& Ishar, A. (2012). Effects of problem-solving strategies in the teaching and learning of engineering drawing subject. Asian Social Science, $8(16)$,

65. 